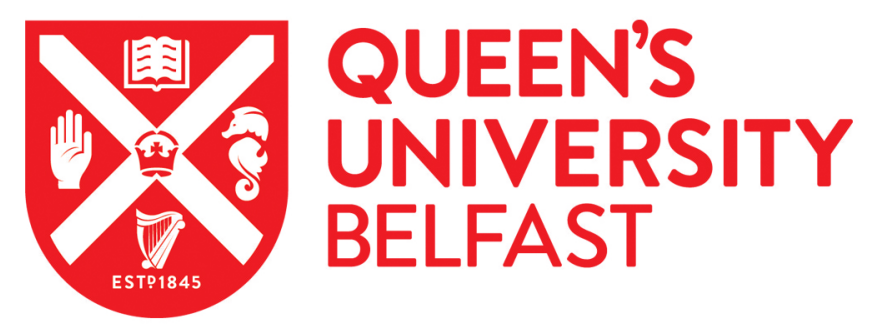

\title{
Single-Domain Antibody-Functionalized pH-Responsive Amphiphilic Block Copolymer Nanoparticles for Epidermal Growth Factor Receptor Targeted Cancer Therapy
}

Gibson, T. J., Smyth, P., McDaid, W. J., Lavery, D., Thom, J., Cotton, G., Scott, C. J., \& Themistou, E. (2018). Single-Domain Antibody-Functionalized pH-Responsive Amphiphilic Block Copolymer Nanoparticles for Epidermal Growth Factor Receptor Targeted Cancer Therapy. ACS Macro Letters, 7(8), 1010-1015. https://doi.org/10.1021/acsmacrolett.8b00461

Published in:

ACS Macro Letters

Document Version:

Peer reviewed version

Queen's University Belfast - Research Portal:

Link to publication record in Queen's University Belfast Research Portal

\section{Publisher rights}

Copyright @ 2018 American Chemical Society. This work is made available online in accordance with the publisher's policies. Please refer to any applicable terms of use of the publisher.

\section{General rights}

Copyright for the publications made accessible via the Queen's University Belfast Research Portal is retained by the author(s) and / or other copyright owners and it is a condition of accessing these publications that users recognise and abide by the legal requirements associated with these rights.

Take down policy

The Research Portal is Queen's institutional repository that provides access to Queen's research output. Every effort has been made to ensure that content in the Research Portal does not infringe any person's rights, or applicable UK laws. If you discover content in the

Research Portal that you believe breaches copyright or violates any law, please contact openaccess@qub.ac.uk. 


\title{
Single-domain Antibody-functionalized pH-Responsive Amphiphilic Block Copolymer Nanoparticles for Epidermal Growth Factor Recep- tor (EGFR) Targeted Cancer Therapy
}

\author{
Thomas J. Gibson, ${ }^{\dagger, \|}$ Peter Smyth, ${ }^{\ddagger}, \|$ William McDaid, ${ }^{\ddagger}$ Daniel Lavery, ${ }^{\dagger}$ Jennifer Thom, ${ }^{\S}$ Graham \\ Cotton, $\$$ Christopher J. Scott ${ }^{*, \ddagger}$ and Efrosyni Themistou ${ }^{*, \dagger}$ \\ †School of Chemistry and Chemical Engineering, Queen’s University Belfast, Belfast BT9 5AG, UK. \\ ${ }^{\ddagger}$ Centre for Cancer Research \& Cell Biology, Queen’s University Belfast, Belfast BT9 7AE, UK. \\ ${ }^{\S}$ Almac Discovery, The Fleming Building, Edinburgh Technopole, Edinburgh EH26 oBE, UK. \\ KEYWORDS. pH-responsive polymers; RAFT polymerization; sdAb-functionalized nanoparticles; targeted cancer \\ therapy; dye release
}

\begin{abstract}
Biocompatible antibody-nanoparticle conjugates have attracted interest as anti-cancer agents due to their potential to selectively target therapeutic agents at disease sites. However, new formulation and conjugation approaches are urgently needed to improve their uniformity for clinical applications. Here, a pH-responsive benzaldehyde functionalized poly[oligo(ethylene glycol) methacrylate-st-para-formyl phenyl methacrylate]- $b$-poly[2-(diisopropyl)aminoethyl methacrylate] [P(OEGMA-st-pFPMA)- $b$-PDPA] block copolymer, prepared by reversible addition-fragmentation chain transfer polymerization, produced PEGylated nanoparticles $(\mathrm{pH}$ 7.4) by single emulsion-solvent evaporation formulation approach. Efficient site-specific attachment of an aminooxy-functionalized anti-EGFR single-domain antibody (sdAb) on these benzaldehyde-decorated nanoparticles is achieved by oxime bond formation. These nanoconjugates can specifically bind EGFR (modified ELISA) and have enhanced uptake over non-functionalized controls in EGFR-positive HeLa cells. Encapsulation of rhodamine $6 \mathrm{G}$ dye and its dispersion upon cellular uptake, consistent with nanoparticle stability loss at $\mathrm{pH}<5.7$, proves their ability to facilitate triggered release in endosomal compartments and highlight their potential for use as next-generation antibody-drug nanoconjugates for therapeutic drug delivery.
\end{abstract}

Amphiphilic block copolymer nanoparticles have been widely explored for the encapsulation of anti-cancer drug therapeutics to both enhance the biodistribution and reduce toxicity profiles of these potent drug molecules. ${ }^{1-3}$ The discovery of 'living' radical polymerisation techniques, such as reversible addition-fragmentation chain-transfer (RAFT) polymerization, ${ }^{4-6}$ has allowed the efficient preparation of a vast range of amphiphilic block copolymers. These polymers can form polymeric nanoparticles by emulsion-solvent evaporation methods. ${ }^{7}$ Introduction of poly(ethylene glycol) (PEG) in their structures ${ }^{8}$ allows the formation of stealth polymeric nanoparticles, which further enhance the encapsulated drug efficacy by slowing its rate of clearance by the reticuloendothelial system.9,10

Whilst it has been clinically demonstrated that nanoparticles can passively target solid tumours through the enhanced permeability and retention effect, they can be further tailored by functionalizing their exterior with targeting ligands (peptides, carbohydrates or antibodies) to endow them with 'active-targeting' properties, promoting enhanced uptake at the tumour site."

To date, different conjugation chemistries have been employed for nanoparticle surface functionalization, including thiol, ${ }^{12}$ amine, ${ }^{13}$ maleimide and carbodiimide approaches. ${ }^{14}$ Given the complexity of the resultant nanoconjugate, there is a need for selective, site-specific and stable conjugation approaches, which will be more amendable to scale-up manufacturing and regulatory standards. ${ }^{5,16}$ One alternative conjugation strategy reported by Wooley et al. involves the incorporation of benzaldehyde groups within the polymer structure. The authors prepared poly(ethylene oxide)-b-poly(4-vinyl benzaldehyde) polymer vesicles with benzaldehyde groups in their vesicular walls, used for cross-linking and functionalization with fluorescein by reductive amination chemistry. ${ }^{17}$

Herein, we synthesise a P(OEGMA-st-pFPMA)-b-PDPA amphiphilic block copolymer by RAFT polymerization in ethanol and investigate its ability to generate nanoparticles via single emulsion-solvent evaporation method (Scheme 1). The polymer was designed with a range of functional properties. Firstly, a PEG-based P(OEGMA-st-pFPMA) hydrophilic block was chosen to give improved biocompatibility and 'stealth-like' properties to the nanoparticles to limit opsonisation. ${ }^{18,19}$ Secondly, the PDPA hydrophobic (at 
Scheme 1. P(OEGMA ${ }_{23}$-st-pFPMA $)$ Macro-CTA Synthesis by RAFT Solution Statistical Copolymerization of OEGMA

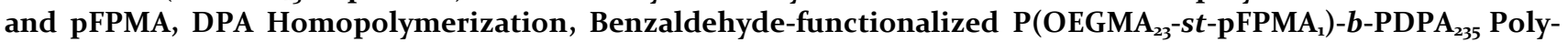
meric Nanoparticle Preparation by Single Emulsion-Solvent Evaporation Method and sdAbs Functionalization.

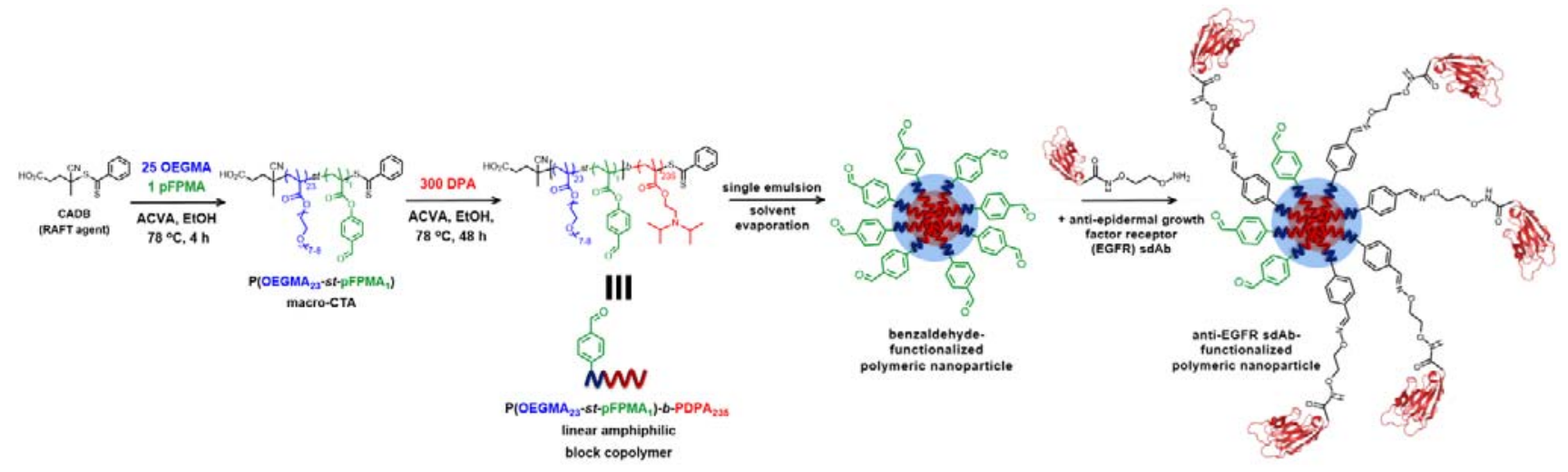

neutral $\mathrm{pH}$ ) block, ${ }^{20-23}$ with a $\mathrm{p} K_{\mathrm{a}}$ value of $\sim 6.4,{ }^{20-22}$ endows the polymer nanoparticles with a $\mathrm{pH}$-responsive intracellular triggered release mechanism of encapsulated cargo. This can take place in the low $\mathrm{pH}$ of the cell endosome, where the PDPA block becomes protonated (hydrophilic), leading to collapse of particles to unimers. Therefore, it can optimally release payloads once internalized in the acidic endosomal compartments. Finally, functionalization of the particle exterior with reactive groups was used to equip them with active targeting capabilities. In our previous work, we utilized carboxyl groups to conjugate targeting moieties via ethyl(dimethylaminopropyl) carbodiimide / $N$-hydroxysuccinimide (EDC/NHS) chemistry. ${ }^{24,25}$ Here, benzaldehyde groups, incorporated in the hydrophilic polymer block, are used to decorate the nanoparticle surface. These groups can react with aminooxy-functionalized antiEGFR sdAb to give stable oxime-bound conjugates ${ }^{26}$ that can selectively target EGFR over-expressing tumour cells. An antibody to target EGFR was chosen as it is well-established that cancer cells found in some lung, breast, head and neck, colon, stomach, ovary, brain and bladder tumors $^{27,28}$ show overexpression of this receptor. EGFR can promote cancer cell proliferation, angiogenesis and invasion whilst simultaneously deactivate programmed cell death (apoptosis) and cell specialization. ${ }^{29}$ Importantly, EGFR is amendable to antibody binding, with two antibodies, Cetuximab ${ }^{30}$ and Panitumumab, ${ }^{31}$ used clinically to abrogate EGFR signalling.

Mao et al. previously synthesized P(OEGMA-stpFPMA)- $b$-PDPA block copolymers in 1,4-dioxane by RAFT polymerization. These were prepared by chain extending a PDPA macromolecular chain transfer agent (macro-CTA) with an OEGMA/pFPMA monomer mixture. ${ }^{32}$ However, Prat et al. recently purported that 1,4-dioxane is a 'hazardous' solvent, and should be avoided, while alcohols (i.e. ethanol, methanol) were ranked as 'recommended'.33

Here, the P(OEGMA-st-pFPMA)-b-PDPA amphiphilic block copolymer was prepared in ethanol. The synthesis was reversed, starting from the shorter $\mathrm{P}$ (OEGMA-stpFPMA) block to ensure good blocking efficiency and better pFPMA incorporation in the POEGMA chain that could be confirmed by proton nuclear magnetic resonance $\left({ }^{1} \mathrm{H}\right.$
NMR) spectroscopy. 4-Cyano-4-(phenylcarbonothi oylthio)pentanoic acid (CADB) RAFT CTA and 4,4'-azobis(4-cyanovaleric acid) (ACVA) initiator were used to polymerize an OEGMA/pFPMA mixture. The resulting P(OEGMA-st-pFPMA) macro-CTA was chain extended with DPA monomer (Scheme 1).

A combination of ${ }^{1} \mathrm{H}$ NMR spectroscopy and size exclusion chromatography (SEC) in tetrahydrofuran (THF) confirmed the successful preparation of the macro-CTA. Its ${ }^{1} \mathrm{H}$ NMR spectrum showed high OEGMA monomer conversion $\left(\sim 92 \%\right.$, Table $\left.\mathrm{S}_{1}\right)$ at $4 \mathrm{~h}$, corresponding to an OEGMA mean degree of polymerisation of 23. The conversion was calculated by comparing the area under the monomer methacrylic peaks at 5.58 and $6.14 \mathrm{ppm}$ with that of the polymer/monomer signals at $4.09 \mathrm{ppm}$. The purified macroCTA (after methanol dialysis) and the block copolymer were characterized by ${ }^{1} \mathrm{H}$ NMR spectroscopy and SEC (THF). For the macro-CTA, the presence of the benzaldehyde proton at 10.0 ppm and absence of monomer methacrylic protons in the ${ }^{1} \mathrm{H}$ NMR spectrum (Figure $\mathrm{S} 1 \mathrm{~A}$ ) verified the successful incorporation of the benzaldehyde monomer into the macro-CTA chain. Although an average of 1 pFPMA unit is incorporated in the polymer chains, and therefore a significant fraction of chains do not contain pFPMA, this does not significantly affect the nanoparticle functionalization, which consists of many polymer chains. The SEC data (Figure 1 and Table S1) indicated that the macro-CTA was polymerized with good control, giving a narrow molecular weight distribution (MWD) with a dispersity $(\nexists)$ value of 1.12. The slight shoulder in the chromatogram at higher molecular weights (MWs) was attributed to ethyleneglycol dimethacrylate cross-linker traces present in the OEGMA monomer from its manufacture, causing chain-chain coupling reactions. However, these were not deemed to be significant enough to hinder the block copolymer synthesis. The number average molecular weight $\left(M_{\mathrm{n}}\right)$ of $9,600 \mathrm{~g} \cdot \mathrm{mol}^{-1}$ obtained for the macro-CTA by SEC was in close agreement with the MW value (10,80o g. $\mathrm{mol}^{-1}$ ) by ${ }^{1} \mathrm{H}$ NMR spectroscopy (Table $\mathrm{S} 1$, entry 1 ).

The macro-CTA chain extension for the P(OEGMA ${ }_{23}$-st$\mathrm{pFPMA}_{1}$ )- $b-\mathrm{PDPA}_{235}$ diblock copolymer formation was performed using 300 molar equivalents of DPA monomer and 


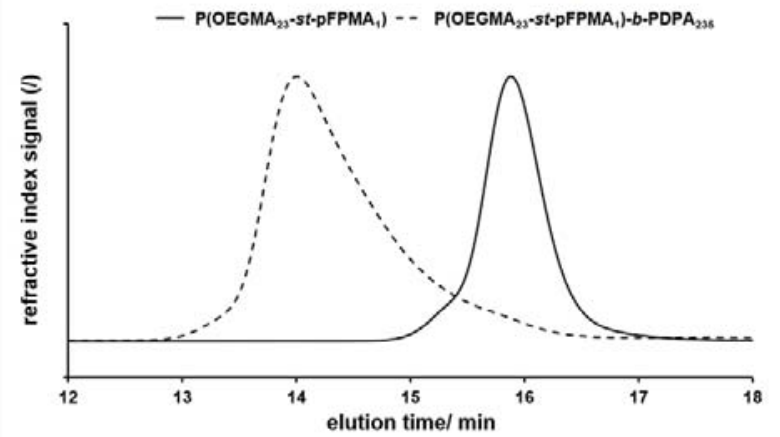

Figure 1. THF SEC chromatograms for $\mathrm{P}\left(\mathrm{OEGMA}_{23}\right.$-stpFPMA $_{1}$ ) macro-CTA and P(OEGMA ${ }_{23}$-st-pFPMA $\left.{ }_{1}\right)-b-\mathrm{PDPA}_{235}$ block copolymer.

$20 \% \mathrm{w} / \mathrm{w}$ solids concentration in ethanol (Scheme 1). The relatively high DPA conversion $(75,8 \%$ after 48 h; Table S1, entry 2) and the presence of the characteristic PDPA isopropyl protons in the ${ }^{1} \mathrm{H}$ NMR spectrum of the purified diblock copolymer (Figure $\mathrm{S} 1 \mathrm{~B}$ ) at 1.04, 2.67 and $3.03 \mathrm{ppm}$, after the macro-CTA (Figure $\mathrm{SiA}$ ) chain extension, confirmed its successful synthesis. As expected, the SEC chromatogram (Figure 1), showed a shift to lower retention time as the DPA monomer was polymerized and incorporated into the polymer chain. The SEC data indicated high macro-CTA blocking efficiency and relatively narrow MWD ( $Đ \sim 1.46$, Table S1) for the block copolymer. The difference between its SEC $M_{\mathrm{n}}\left(37,400 \mathrm{~g} \cdot \mathrm{mol}^{-1}\right)$ and ${ }^{1} \mathrm{H}$ NMR MW (6o,900 g. mol $^{-1}$; Table S1, entry 2 ) could be due to the broader MWD (tailing effect in the chromatogram), attributed to interactions between the PDPA side chains and SEC columns, and/or slow initiation for the second block.

Next, the benzaldehyde-functionalized block copolymer was used to produce nanoparticles by a single emulsionsolvent evaporation approach (Scheme 1), used in our previous work for preparation of PLGA and PLGA-PEG nanoparticle formulations. ${ }^{24,25,34}$ Assessment by dynamic light scattering (DLS) demonstrated that this approach successfully generated nanoparticles with a mean hydrodynamic diameter of $\sim 230 \mathrm{~nm}$ (Figure 2 and Table S2). A uniform monodisperse formulation was obtained (low $Ð$ value of o.047). Size and uniformity was subsequently confirmed by nanoparticle tracking analysis (NTA, Figure $\mathrm{S}_{2}$ ) and scanning electron microscopy (SEM) imaging (Figure 2), confirming formation of nanoparticles at neutral $\mathrm{pH}$.

The nanoparticle stability was examined at various temperatures $\left(4^{\circ} \mathrm{C}\right.$, room temperature $\left(\sim 22^{\circ} \mathrm{C}\right)$ and $\left.37^{\circ} \mathrm{C}\right)$ for 42 days. DLS measurements (Figure $\mathrm{S}_{3}$ ) taken at regular intervals during storage illustrated that the nanoparticle formulation exhibited remarkable stability. The nanoparticle size remained relatively stable throughout this time period at all temperatures, with $Ð$ values not exceeding 0.20.

A key attribute of the nanoparticle design strategy was their $\mathrm{pH}$ responsiveness, to allow rapid release of encapsulated payloads in intracellular endo/lyosomal compartments. A pH decrease, below the PDPA block $\mathrm{p} K_{\mathrm{a}}$ value $(\sim 6.4)$, protonates its tertiary amine groups, rendering it hydrophilic. This results in nanoparticle collapse and release of encapsulated cargo. To examine the structural integrity of the nanoparticle solutions, their turbidity (450 $\mathrm{nm}$ ) was examined across a $\mathrm{pH}$ range. Nanoparticles appear turbid and strongly scatter visible light. In contrast, unimers, due to their very small size, cannot scatter light as efficiently. The obtained UV-Vis data (Figure $\mathrm{S}_{4}$ ) showed a gradual increase in transmittance with $\mathrm{pH}$ drop, consistent with nanoparticle collapse to unimers, with full collapse appearing by $\mathrm{pH}$ 5.7.

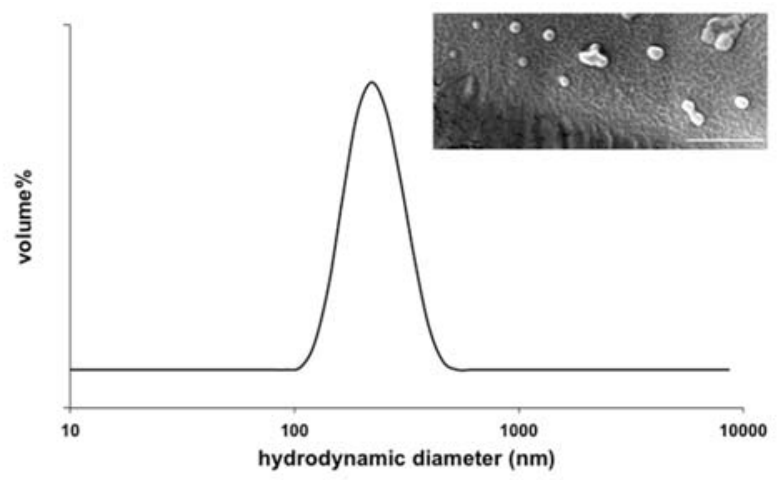

Figure 2. Hydrodynamic diameter distribution of P(OEGMA 23 -st-pFPMA 1 - $b$-PDPA 235 nanoparticles by DLS (PBS buffer, $\mathrm{pH}$ 7.4) and SEM image.

Next, fluorescent nanoparticles were produced by entrapping rhodamine $6 \mathrm{G}$ as a model hydrophobic agent and drug molecule surrogate. Nanoparticles of $263 \mathrm{~nm}$ hydrodynamic diameter (DLS, Table S2) were prepared as before via addition of rhodamine $6 \mathrm{G}$ into the organic phase. Subsequently, a release study was conducted at $\mathrm{pH} 7.4,6.5$ and $\mathrm{pH}$ 5.5, mimicking the release patterns outside the cell, within early and late stage endosomes, respectively. At $\mathrm{pH}$ 7.4 and 6.5 , a relatively controlled dye release was observed over time (Figure $\mathrm{S}_{5}$ ), through diffusion from the nanoparticles. At the lower $\mathrm{pH}$ (5.5), a significantly faster burst release was observed, indicative of the loss of nanoparticle integrity at this $\mathrm{pH}$, triggering release of the cargo.

Visualization of the fate of these rhodamine $6 \mathrm{G}$ loaded nanoparticles in cell-based assays was then carried out. A549 lung epithelial cells are endocytotic and can be used to examine uptake of particulates. ${ }^{35,36}$ Parallel cell cultures in presence or absence of $1 \mu \mathrm{M}$ bafilomycin were prepared before exposure to rhodamine $6 \mathrm{G}$ loaded nanoparticles. Representative micrographs (Figure 3) showed that without bafilomycin pretreatment, rhodamine fluorescence was observed in the cells in a rather diffuse pattern (orange arrows) compared to the punctate staining evidenced in the bafilomycin treated cells (green arrows). Bafilomycin inhibits the acidification of endosomal compartments through its action on V-ATPases. ${ }^{37}$ Therefore, the observed punctate staining is suggestive of improved nanoparticle integrity, due to the maintenance of endosomal $\mathrm{pH}$ above the PDPA $\mathrm{p} K_{\mathrm{a}}$ value. These in vitro and cell-based assessments indicate that this block polymer can successfully generate nanoparticles (at neutral $\mathrm{pH}$ ) that lose integrity and release encapsulated contents at endosomal $\mathrm{pH}$. 


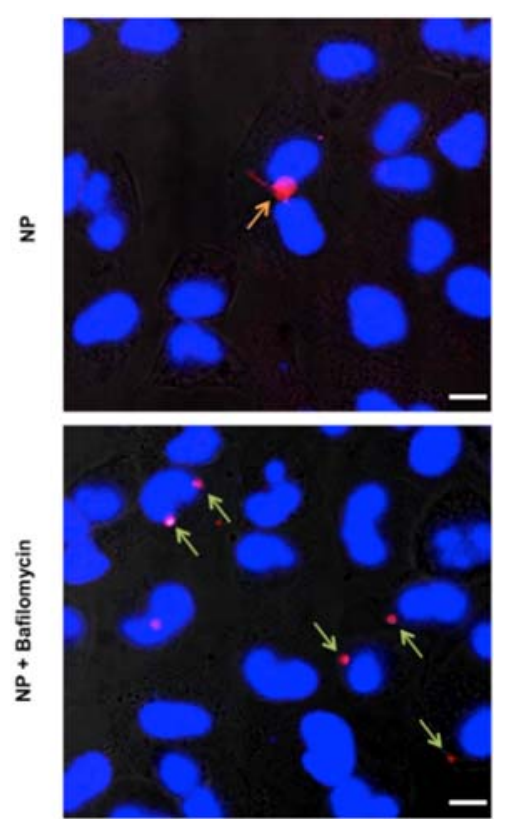

Figure 3. A549 cells treated with rhodamine 6G nanoparticles (NP) in presence or absence of bafilomycin. Scale bars $=10 \mu \mathrm{m}$.

The biocompatibility of the formulation was next assessed. Nanoparticle solutions (o-0.2 $\mathrm{mg} / \mathrm{mL}$ ) were incubated with A549 cells. CellTiter-Glo assay ( $48 \mathrm{~h}$ ) showed no significant alterations in cell viability, suggesting that the particles were well tolerated by the cells (Figure S6).

The benzaldehyde functionality of the nanoparticles was used for conjugating an aminooxy-functionalized sdAb targeting EGFR. This approach was chosen as it facilitates a site-specific conjugation, resulting in formation of a stable oxime bond. This has been previously reported to be the linkage of choice for conjugating molecules via carbon-nitrogen double bonds, due to its increased robustness to hydrolysis. ${ }^{38}$ The EGFR binding sdAb $7 \mathrm{C}_{12}$ was generated with a unique C-terminal aminooxy functionality. ${ }^{39,40}$ Its characterization was performed by SDS PAGE analysis and electrospray mass spectrometry (Figure $\mathrm{S}_{7}$ ). Addition of sdAb $(100 \mu \mathrm{g})$ to nanoparticles $(2 \mathrm{mg})$, followed by $24 \mathrm{~h}$ agitation at $4{ }^{\circ} \mathrm{C}$ in the presence of para-phenylenediamine catalyst, resulted in a sdAb conjugation of $5.25 \mu \mathrm{g} / \mathrm{mg}$ polymer. The antibody-functionalized nanoparticles hydrodynamic diameter by DLS was $\sim 263 \mathrm{~nm}$ (Table S2).

A modified ELISA procedure was developed using immobilized EGFR (recombinant human EGFR-Fc chimeric protein) on microtiter plates to ascertain the ability of the $\mathrm{sdAb}$ to bind to its cognate receptor after conjugation to the nanoparticles (Figure $4 \mathrm{~A}$ ). Rhodamine $6 \mathrm{G}$ loaded nanoparticles were used for the detection of nanoparticle binding to the immobilized receptor. Binding was assessed for nude nanoparticles with no sdAb [P(OEGMA ${ }_{23}$-st$\mathrm{pFPMA}_{1}$ )- $b$-PDPA ${ }_{235}$ ], used as a control, and targeted nanoparticles with sdAb on their surface $\left(\mathrm{P}\left(\mathrm{OEGMA}{ }_{23}\right.\right.$-stpFPMA $_{1}$ )- $b$-PDPA 235 +anti-EGFR) in the presence (+EGFR) and absence (-EGFR) of EGFR-Fc by fluorescence spectroscopy. A three-fold increase of particle binding to EGFR was observed for anti-EGFR sdAb nanoparticles compared to the control. This indicated that the conjugation procedure had not affected the ability of the sdAb paratope to recognize and bind its cognate epitope on the EGFR protein.
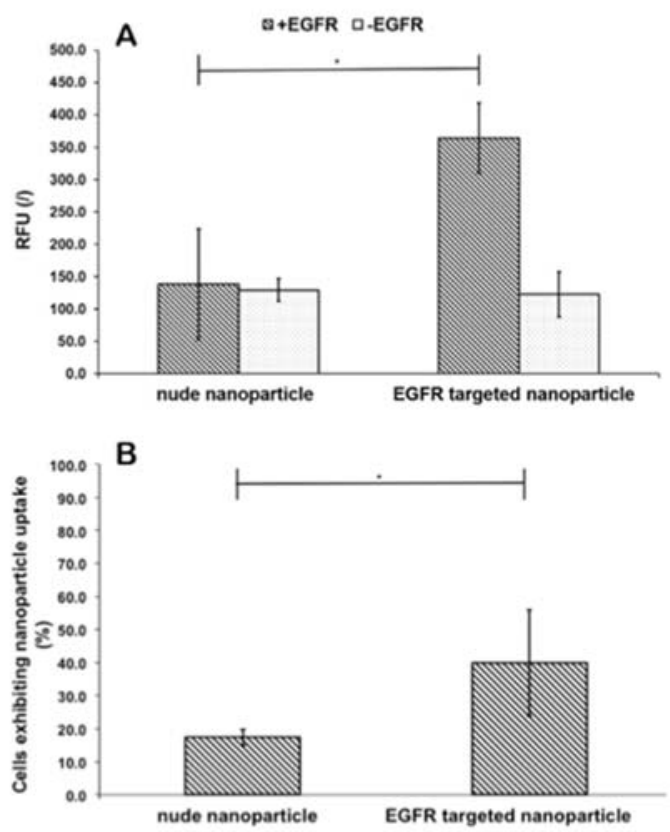

Figure 4. (A) Binding assessment of anti-EGFR sdAb functionalized (EGFR targeted nanoparticle) and non-functionalized (nude nanoparticle control) nanoparticles to immobilized EGFR-Fc. Presence (+EGFR) and absence (-EGFR) of EGFR Fc. Mean \pm standard deviation (SD); one-way ANOVA and Tukey's post-hoc test ( $\left.{ }^{*} \mathrm{p} \leq 0.05\right)$. (B) Quantitative analysis showing percentage of HeLa cells exhibiting nanoparticle uptake; 4 fields of view sampled for each treatment. Data: mean \pm SD; unpaired t-test $\left({ }^{*} \mathrm{p} \leq 0.05\right)$.

In vitro cellular uptake was also investigated. HeLa cells were incubated with nanoparticles for $1 \mathrm{~h}$ at $4^{\circ} \mathrm{C}$ to allow binding, whilst prohibiting cellular internalization..$^{41}$ Cells were washed to remove any unbound nanoparticles before incubation $\left(37^{\circ} \mathrm{C}, 2 \mathrm{~h}\right)$, enabling the uptake of surfacebound nanoparticles. The expression of EGFR on the surface of HeLa cells was confirmed by fluorescence-activated cell sorting (FACS) analysis, proving that these cells were a suitable model to study nanoparticle-EGFR interactions (Figure S8). The level of nanoparticle uptake was quantified using confocal microscopy (Figure S9). The results highlight that sdAb targeting facilitated enhanced nanoparticle uptake. The antibody-functionalized nanoparticles showed higher uptake than the nude nanoparticles (Figure 4B).

Here, we have described the synthesis of a novel benzaldehyde-functionalized amphiphilic block copolymer, which was successfully used to prepare $\mathrm{pH}$-responsive nanoparticles. We then show successful site-specific conjugation of aminooxy-functionalized sdAb to facilitate active targeting of these novel nanoparticles. Although further work on the biocompatibility and biodistribution of nanoparticles will be necessary in the future, we envisage similar renal excretion to other methacrylic polymer nanostructures evaluated. ${ }^{42}$ In conclusion, this approach provides an ideal strategy for the development of next-generation targeted cancer therapy. 


\section{ASSOCIATED CONTENT}

\section{Supporting Information.}

Experimental details; polymer SEC and 'H NMR data; nanoparticle NTA, DLS, UV-Vis and intrinsic toxicity, fluorescent dye release data and in vitro cell uptake; aminooxy-functionalised EGFR sdAb SDS PAGE and electrospray mass spectroscopy data; HeLa cell EGFR expression by flow cytometry. This material is available free of charge via the Internet at http://pubs.acs.org.

\section{AUTHOR INFORMATION}

\section{Corresponding Authors}

* E-mail: e.themistou@qub.ac.uk (E.T.)

* E-mail: c.scott@qub.ac.uk (C.J.S.)

\section{Author Contributions}

"These authors contributed equally. Notes

The authors declare no competing financial interest.

\section{ACKNOWLEDGMENTS}

The authors acknowledge the Department of Employment and Learning (DEL), and Engineering and Physical Sciences Research Council (EPSRC) (S3802ASA) for Ph.D. studentship funding, Health and Social Care in Northern Ireland (HSCNI) (STL/5010/14, MRC grant MC_PC_15013) and Medical Research Council (MRC) Confidence in Concept funding.

\section{REFERENCES}

(1) Sanna, V.; Pala, N.; Sechi, M. Targeted Therapy using Nanotechnology: Focus on Cancer. Int. J. Nanomedicine. 2014, 9, 467-483.

(2) Jabir, N. R.; Tabrez, S.; Ashraf, G. M.; Shakil, S.; Damanhouri, G. A.; Kamal, M. A. Nanotechnology-based Approaches in Anticancer Research. Int. J. Nanomedicine. 2012, 7, 43914408.

(3) Liang, X.-J.; Chen, C.; Zhao, Y.; Wang, P. C. Circumventing Tumor Resistance to Chemotherapy by Nanotechnology. Methods Mol. Biol. 2o10, 596, 467-488.

(4) Moad, G.; Rizzardo, E.; Thang, S. H. Living Radical Polymerization by the RAFT Process. Aust. J. Chem. 2005, 58, 379410.

(5) Chiefari J.; Chong Y. K.; Moad, G.; Rizzardo E.; Thang, S. H. Living Free-Radical Polymerization by Reversible Addition-Fragmentation Chain Transfer: The RAFT Process. Macromolecules 1998, 31, 5559-5562.

(6) Moad, G.; Rizzardo, E.; Thang, S. H. Living Radical Polymerization by the RAFT Process: A Second Update. Aust. J. Chem. 2009, 62, 1402-1472.

(7) Kuskov, A. N.; Voskresenskaya, A. A.; Goryachaya, A.; Artyukhov, A. A.; Shtilman, M. I.; Tsatsakis, A. M. Preparation and Characterization of Amphiphilic Poly-N-vinylpyrrolidone Nanoparticles Containing Indomethacin. J. Mater. Sci. Mater. Med. 2010, 21, 1521-1530.

(8) Kamaly, N.; Xiao, Z.; Valencia, P. M.; Radovic-Moreno, A. F.; Farokhzad, O. C. Targeted Polymeric Therapeutic Nanoparticles: Design, Development and Clinical Translation. Chem. Soc. Rev. 2012, 41, 2971-3010.

(9) Knop, K.; Hoogenboom, R.; Fischer, D.; Schubert, U. S. Poly(ethylene glycol) in Drug Delivery: Pros and Cons as well as Potential Alternatives. Angew. Chem. Int. Ed. 2010, 62886308.
(10) Gref, R.; Minamitake, Y.; Peracchia, M. T.; Trubetskoy, V.; Torchilin, V.; Langer, R. Biodegradable Long-circulating Polymeric Nanospheres. Science 1994, 263, 1600-1603.

(11) Fay, F.; Scott, C. Antibody-targeted nanoparticles for cancer therapy. J. Immunotherapy 2011, 3, 381-394.

(12) Rosselgong, J.; Blanazs, A.; Chambon, P.; Williams, M.; Semsarilar, M.; Madsen, J.; Battaglia, G.; Armes, S. P. Thiol-functionalized Block Copolymer Vesicles. ACS Macro Lett. 2012, 1, 1041-1045.

(13) Wang, H.; Zhuang, J.; Thayumanavan, S. Functionalizable Amine-based Polymer Nanoparticles. ACS Macro Lett. 2013, 2, 948-951.

(14) Nicolas, J.; Mura, S.; Brambilla, D.; Mackiewicz, N.; Couvreur, P. Design, Functionalization Strategies and Biomedical Applications of Targeted Biodegradable/Biocompatible Polymer-based Nanocarriers for Drug Delivery. Chem. Soc. Rev. 2013, 42, 1147-1235.

(15) Sapsford, K. E.; Algar, W. R.; Berti, L.; Gemmill, K. B.; Casey, B. J.; Oh, E.; Stewart, M. H.; Medintz, I. L. Functionalizing Nanoparticles with Biological Molecules: Developing Chemistries that Facilitate Nanotechnology. Chem. Rev. 2013, 113, 1904-2074.

(16) Greene, M.; Richards, D. A.; Nogurira, J.; Campbell, K.; Smyth, P.; Fernandez, M.; Scott, C. J.; Chudasama, V. Generating Next-Generation Antibody-Nanoparticle Conjugates through the Oriented Installation of Non-Engineered Antibody Fragments. Chem. Sci. 2018, 9, 79-87.

(17) Sun, G.; Fang, H.; Cheng, C.; Lu, P.; Zhang, K.; Walker, A. V; Taylor, J.-S. A.; Wooley, K. L. Benzaldehyde-functionalized Polymer Vesicles. ACS Nano 2009, 3, 673-681.

(18) Li, Y.-P.; Pei, Y.-Y.; Zhang, X.-Y.; Gu, Z.-H.; Zhou, Z.-H.; Yuan, W.-F.; Zhou, J.-J.; Zhu, J.-H.; Gao, X.-J. PEGylated PLGA Nanoparticles as Protein Carriers: Synthesis, Preparation and Biodistribution in Rats. J. Control. Release. 2001, 71, 203-211.

(19) Walkey, C. D.; Olsen, J. B.; Guo, H.; Emili, A.; Chan, W. C. W. Nanoparticle Size and Surface Chemistry Determine Serum Protein Adsorption and Macrophage Uptake. J. Am. Chem. Soc. 2012, 134, 2139-2147.

(20) Blanazs, A.; Massignani, M.; Battaglia, G.; Armes, S. P.; Ryan, A. J. Tailoring Macromolecular Expression at Polymersome Surfaces. Adv. Funct. Mater. 2009, 19, 2906-2914.

(21) Lomas, H.; Canton, I.; MacNeil, S.; Du, J.; Armes, S. P.; Ryan, A. J.; Lewis, A. L.; Battaglia, G. Biomimetic pH Sensitive Polymersomes for Efficient DNA Encapsulation and Delivery. Adv. Mater. 2007, 19, 4238-4243.

(22) Liang, K.; Such, G. K.; Johnston, A. P. R.; Zhu, Z.; Ejima, H.; Richardson, J. J.; Cui, J.; Caruso, F. Endocytic pH-Triggered Degradation of Nanoengineered Multilayer Capsules. Adv. Mater. 2014, 26, 1901-1905.

(23) Larnaudie, S. C.; Brendel, J. C.; Jolliffe, K. A.; Perrier, S. pHResponsive, Amphiphilic Core-shell Supramolecular Polymer Brushes from Cyclic Peptide-polymer Conjugates. ACS Macro Lett. 2017, 6, 1347-1351.

(24) Spence, S.; Greene, M. K.; Fay, F.; Hams, E.; Saunders, S. P.; Hamid, U.; Fitzgerald, M.; Beck, J.; Bains, B. K.; Smyth, P.; Themistou, E.; Small, D. M.; Schmid, D.; Kane, C. M. O.; Fitzgerald, D. C.; Abdelghany, S. M.; Johnston, J. A.; Fallon, P. G.; Burrows, J. F.; Mcauley, D. F.; Kissenpfennig, A.; Scott, C. J. Targeting Siglecs with a Sialic Acid-decorated Nanoparticle Abrogates Inflammation. Sci. Transl. Med. 2015, 7, 1-13.

(25) Schmid, D.; Fay, F.; Small, D. M.; Jaworski, J.; Riley, J. S.; Tegazzini, D.; Fenning, C.; Jones, D. S.; Johnston, P. G.; Longley, D. B.; Scott, C. Efficient Drug Delivery and Induction of Apoptosis in Colorectal Tumors Using a Death Receptor 5Targeted Nanomedicine. J. Am. Soc. Gene Cell Ther. 2014, 22, 2083-2092. 
(26) Wendeler, M.; Grinberg, L.; Wang, X.; Dawson, P. E.; Baca, M. Enhanced Catalysis of Oxime-based Bioconjugations by Substituted Anilines. Bioconjug. Chem. 2014, 25, 93-101.

(27) Woodburn, J. The Epidermal Growth Factor Receptor and Its Inhibition in Cancer Therapy. Pharmacol. Ther. 1999, 82, 241250.

(28) Sharma, S. V.; Bell, D. W.; Settleman, J.; Haber, D. A. Epidermal Growth Factor Receptor Mutations in Lung Cancer. Nat. Rev. Cancer. 2007, 7, 169-181.

(29) Kris, M.; Natale, R.; Herbst, R.; Al, E. Efficacy of Gefitinib, an Inhibitor of the Epidermal Growth Factor Receptor Tyrosine Kinase, in Symptomatic Patients with Non-small Cell Lung Cancer: A Randomized Trial. JAMA 2003, 290, 2149-2158.

(30) Cunningham, D.; Humblet, Y.; Siena, S.; Khayat, D.; Bleiberg, H.; Santoro, A.; Bets, D.; Mueser, M.; Harstrick, A.; Verslype, C.; Chau, I.; Van Cutsem, E. Cetuximab Monotherapy and Cetuximab plus Irinotecan in Irinotecan-Refractory Metastatic Colorectal Cancer. N. Engl. J. Med. 2004, 351, 337-345.

(31) Douillard, J.-Y.; Oliner, K. S.; Siena, S.; Tabernero, J.; Burkes, R.; Barugel, M.; Humblet, Y.; Bodoky, G.; Cunningham, D.; Jassem, J.; Rivera, F.; Kocákova, I.; Ruff, P.; BłasińskaMorawiec, M.; Šmakal, M.; Canon, J. L.; Rother, M.; Williams, R.; Rong, A.; Wiezorek, J.; Sidhu, R.; Patterson, S. D. Panitumumab-FOLFOX 4 Treatment and RAS Mutations in Colorectal Cancer. N. Engl. J. Med. 2013, 369, 1023-1034.

(32) Mao, J.; Li, Y.; Wu, T.; Yuan, C.; Zeng, B.; Xu, Y.; Dai, L. A Simple Dual-pH Responsive Prodrug-Based Polymeric Micelles for Drug Delivery. ACS Appl. Mater. Interfaces 2016, 8, 17109-17117.

(33) Prat, D.; Wells, A.; Hayler, J.; Sneddon, H.; McElroy, C. R.; Scott, J. P.; Xu, J.; Watanabe, K. CHEM21 Selection Guide of Classical- and Less Classical-Solvents. Green Chem. 2016, 18, 288-296.

(34) Bains, B. K.; Greene, M. K.; Mcgirr, L. M.; Dorman, J.; Farrow, S. N.; Scott, C. J. Encapsulation of the p38 MAPK Inhibitor GSK $678361 \mathrm{~A}$ in Nanoparticles for Inflammatory-based Disease States. J. Interdiscip. Nanomedicine 2016, 1, 85-92.
(35) Stearns, R. C.; Paulauskis, J. D.; Godleski, J. J. Endocytosis of Ultrafine Particles by A549 Cells. Am. J. Respir. Cell. Mol. Biol. 2001, 24, 108-115.

(36) Nowak, J. S.; Mehn, D.; Nativo, P.; García, C. P.; Gioria, S.; Ojea-jiménez, I.; Gilliland, D. Silica Nanoparticle Uptake Induces Survival Mechanism in A549 Cells by the Activation of Autophagy but not Apoptosis. Toxicol. Lett. 2014, 224, 84-92.

(37) Yoshimori, T.; Yamamoto, A.; Moriyamas, Y.; Futais, M.; Tashiroq, Y. Bafilomycin-aı, a Specific Inhibitor of VacuolarType H+-Atpase, Inhibits Acidification and Protein-Degradation in Lysosomes of Cultured-Cells. J. Biol. Chem. 1991, 266, 17707-17712.

(38) Kalia, J.; Raines, R. T. Hydrolytic Stability of Hydrazones and Oximes. Angew. Chem. Int. Ed. 20o8, 47, 7523-7526.

(39) Gainkam, L. O. T.; Huang, L.; Caveliers, V.; Keyaerts, M.; Hernot, S.; Vaneycken, I.; Vanhove, C.; Revets, H.; Baetselier, P. De; Lahoutte, T. Comparison of the Biodistribution and Tumor Targeting of Two 99mTc-Labeled Anti-EGFR Nanobodies in Mice, Using Pinhole SPECT/Micro-CT. J. Nucl. Med. 2008, 49, 788-795.

(40) Thom, J.; Anderson, D.; Mcgregor, J.; Cotton, G. Recombinant Protein Hydrazides: Application to Site-specific Protein PEGylation. Bioconjug. Chem. 2011, 22, 1017-1020.

(41) Straubinger, R.; Hong, K.; Friend, D.; Papahadjopoulos, D. Endocytosis of Liposomes and Intracellular Fate of Encapsulated Molecules: Encounter with a Low $\mathrm{pH}$ Compartment after Internalization in Coated Vesicles. Cell 1983, 32, 10691079 .

(42) Etrych, T.; Subr, V.; Strohalm, J.; Sirova, M.; Rihova, B.; Ulbrich, K. HPMA Copolymer-doxorubicin Conjugates: The Effects of Molecular Weight and Architecture on Biodistribution and In Vivo Activity. J. Control. Release 2012, 164, 346354 . 


\section{For Table of Contents Use Only}

Single-domain Antibody-functionalized pH-Responsive Amphiphilic Block Copolymer Nanoparticles for Epidermal Growth Factor Receptor (EGFR) Targeted Cancer Therapy

Thomas J. Gibson, Peter Smyth, William McDaid, Daniel Lavery, Jennifer Thom, Graham Cotton, Christopher J. Scott and Efrosyni Themistou

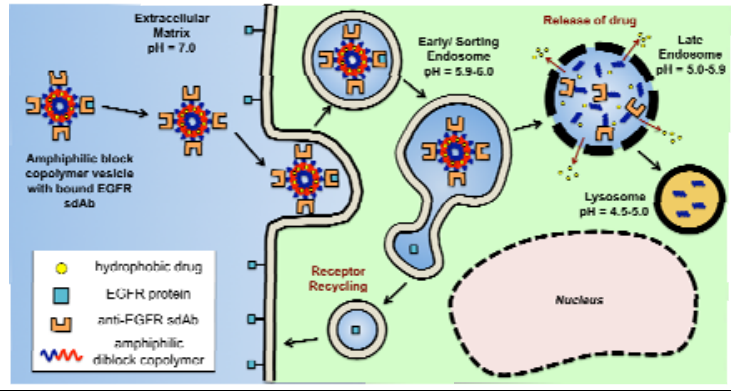

